\title{
Local management of common property. Theory and practice of the common pastures in Morocco
}

\section{Bernhard Venema}

\section{OpenEdition}

\section{Journals}

Édition électronique

URL : http://journals.openedition.org/apad/1972

DOI : 10.4000/apad. 1972

ISSN : 1950-6929

Éditeur

LIT Verlag

Édition imprimée

Date de publication : 1 décembre 1994

Référence électronique

Bernhard Venema, «Local management of common property. Theory and practice of the common pastures in Morocco », Bulletin de l'APAD [En ligne], 8 | 1994, mis en ligne le 23 novembre 2007, consulté le 08 septembre 2020. URL : http://journals.openedition.org/apad/1972 ; DOI : https:// doi.org/10.4000/apad.1972

Ce document a été généré automatiquement le 8 septembre 2020.

Bulletin de I'APAD 


\title{
Local management of common property. Theory and practice of the common pastures in Morocco
}

\author{
Bernhard Venema
}

Abstract

1 Since the eighties the World Bank, in collaboration with the Moroccan authorities, is trying to change existing sheephusbandry practices in the Middle Atlas in order to arrest soil erosion. In accordance with development philosophy local organisations are given a great role in the management of the project. The research showed that the local herders' associations had become completely incorporated into the local power network. The influential herd owners had appropriated the advantages connected with the local associations whereas several responsibilities, as for example the need to decrease stock numbers, were passed on to the less influential, notably the immigrant herdsmen. The reliance on local organisations in fact ran counter to a sustainable environment. Local management of common natural resources can only be successful if the Moroccan authorities are willing to address local power distribution. Examples are given that the authorities were able to do so which, in turn, helped to decrease environmental degradation.

Introduction

2 In a FAO-study is stated that about US\$1000 million of donor funds were ineffectively spent during the 1970s' and 1980s on group ranches and grazing schemes in Africa because the schemes paid insufficient attention to local cultures and needs. Since the 1980s the development set, captained by the World Bank, paid more attention to the role local institutions and organisations can play in projects and programs. After a critical survey of livestock projects, Eicher and Baker (1982:170), put forward: "Large-scale government ranches were tried in numerous countries over the 1960-75 period with the support of the World Bank and several bilateral donors. But commercial and government ranches have performed poorly in most countries. The failure of numerous commercial and government ranches in the past two decades, 
supplemented with increasing population pressure and concerns with equity, have forced many governments to de-emphasize commercial ranches and move toward group ranches, grazing blocks (associations), and assistance to small herders". The anthropologist-consultant Dyson-Hudson argues in favour of livestock projects which fits closely with the population too. He therefore prefers local livestock associations to 'group and company ranches' (1985).

3 In several studies and policy-documents it is not only suggested to link up with local patterns of organizations but to increase their influence (but to assign them a more prominent role) too. This subscribes the view that the state has failed as a development-agency as was mentioned above. In April 1991 the FAO and the Dutch Ministry of Agriculture, Nature Management and Fisheries organized a conference on 'Sustainable Agriculture and Rural Development'. In the contribution on livestock production it is argued that land degradation can only be stopped when overgrazing can be kept under control. This will only succeed when there is communal control over grazing pressure and pastoral groups or associations are created or strenghened (FAO, $\left.\mathrm{n}^{\circ} 3,1991: 15,19\right)$. In the contribution on 'Social and Institutional Aspects of a Sustainable Agriculture (FAO, $\mathrm{n}^{\circ}$ ), it is put forward that communal land must be preserved because it is a last avenue for the poor section of pastoralists. For a sustainable management of the common pastures the local community must have a decisive role in planning and implementation. This means the devolution of power from the state to local groups. In many policy documents and reports this view of the $F$ $\mathrm{AO}$ is endorsed.

4 In this contribution I will level criticisms against the role local institutions should play in development projects, in casu the importance attached to local management of common rangeland. Two staff-members of the World Bank (Bromley and Cernea, 1989) argue that in the

5 'group ranching project' in the Middle Atlas, Morocco, the local authorities have succeeded in introducing grazing roles, including stocking rates while the lineage-council had been able to introduce grazing fees and controlled the access to the common pastures.

6 We are left in the dark which facts endorse this statement of the two World Bank functionaries. We will demonstrate that in this project the traditional institutions pertaining to local management of natural resources have since long been undermined by a process of increasing polarization. The involvement of local groups in the management of common rangeland means little more than that local power constellations are reinforced. In addition, in this as well as in many other documents it is overlooked who constitutes the local population. What are the rights of the immigrant families, especially if they live in the area for a time-span of a generation or more ? At last, must we accept the free play of societal forces or is there also a role to play for the government? Successively these questions will be treated below.

The myth of an egalitarian society

7 The Beni Mguild Berbers live in the central-northern part of the Middle Atlas. Their main activity is sheep herding. In the summer the sheep are pastured on the highlands, in the winter on the lowlands. It is a type of transhumance with a vertical migration pattern. Because of these seasonal movements they lived in tents. In addition to tents they also had houses, made of stones, loam and wood in which agricultural equipment and grain were stored. The cluster of houses, called ighrem, most often was located in 
the winter pastures or in the transitional area between summer and winter pastures. According to historical documents families left the house in spring to live in the tent in the summer pastures. Only a guard remained in the house. Nowadays the Beni Mguild are settled and it is the shepherd who lives in a tent on the far-off pastures.

The Beni Mguild were incorporated in the market-economy since centuries. The trade between Europe and West Soudan passed in transit through this area: the caravan routes traversed right across the pastures of the Beni Mguild. Azrou, the most important marketplace of the Beni Mguild, was part of this trading route. On this market they sold hides, wool, butter and cattle in exchange for tea, sugar and weapons. The trade activities yielded the Beni Mguild important secondary revenues because they levied tribute from passing traders. Several records of travel give ample attention to the fact that the tributes were high and were levied quite often several times. It occurred that trade was suspended for this reason (see a.o. Rohlfs, 1868).

The levying of tribute did not only occur among the Beni Mguild but everywhere where the central government was weak. Throughout the history we see that the Sultanate tried to submit the tribes in order to establish a trade monopoly. But sooner or later the central government lost its hegemony and it is only from the rule of Hassan I (1873-1894) onwards that the Beni Mguild were forced to collaborate with the central government.

Due to the incorporation of the Beni Mguild in trade capitalism patterns of power concentration had developed. According to French researchers the Beni Mguild society could be characterized as a segmentary society. According to them the lineage formed the basic unit of the camp of tents and of the ighrem. Every lineage had a council of elder (djema) which took the important decisions as regards the date of sowing, the appointment of a Koran teacher etc. One of the important issues the lineage-council dealt with was the moment of departure to the summer and the winter pastures. It was very important that the winter pastures were left ungrazed long enough in order that grass could grow sufficiently enough before it was grazed anew.

11 Several lineages, sharing common interests, could constitute a tribe and tribes could together make up a confederation. So the Beni Mguild are in fact composed of three tribes, the Irklaouan, the Ait Abdi and the Ait Arfa de Guigou. Every tribe defended its rancheland, wells and its right to levy tribute vis à vis the other tribes. The tribe had a council too, composed of representives of the lineages. In the case several lineages had the right of access to the same pasture it was the tribal council which decided about the grazing pattern of the lineages concerned.

This analysis by the researchers of the day presented an idealized version of the facts. As regards cooperation between lineages we have to be realistic. Outside the lineage, even inside the lineage, clublaw counted. Dabancens (1951) argued: "The greater the tent the more male adults it will count able to bear arms, the greater its influence in the djema" (transl. by author). When lieutenant Bertschi in 1911 scouted the area he noted such a limited power of the lineage-councils compared to local influentials that it seemed to him that the Beni Mguild were ruled by anarchy (A.N. D.A.I. $n^{\circ} 407$ ).

13 In view of these social patterns it is not amazing there were strong differences in wealth too. Important tribal elder had been able to enrich themselves by monopolizing the levying of tribute (Foucault, $1995: 7$ ). In addition, some relative permanent patron-client relations had developed. Many immigrants had settled themselves in Azrou and in some other centres and they exploited the forests on account of 
middlemen of Fez and Meknes. These woodcutters were only able to do so because they or their superieurs had paid protection money. Because the woodcutters had established themselves permanently, the latter disposed of a continuous flow of side-revenues which they invested in cattle or in land.

From the first tribal leaders, on which we have some facts, the following is known. A man from the lineage Ait Amar (Irklaouan), Aarabe, was the tribal leader. Because of his strong position in the tribe he was appointed as caid (sort of district officer) of the Irklaouan by Sultan Hassan I. He obtained the privilege to levy tax of which he could appropriate a part. He became very soon rich and he built a fortress in Azrou and disposed of body-guards. He was succeeded by his son who was able to obtain a comfortable standard of living too as we will see below. Another caid, appointed by a rival of the Sultan took advantage of the turbulent times just before the Protectorate to occupy fertile land near Azrou next to five wells. The mills he constructed there gave him additional revenues. These examples prove that before the Protectorate the Beni Mguild society could not be depicted as egalitarian.

Increasing differentiation as a consequence of the Protectorate

With the establishment of the Protectorate economic polarization increased considerably. Contrary to the policy in Algeria the colonial government in Morocco tried to involve the local authorities in policy-implementation. This was also the case among the Beni Mguild. Those tribal leaders, already appointed as a caid by the Sultan, could continue to occupy their post as long as they were capable to do the job. Imitating the practices of the colons who had established themselves in Azrou, the tribal leaders bought private land from the tribesmen too. They had ample opportunity to do this because of the income deriving from tax-collecting. Just as the colons did they also pinched communal land before the colonial administration was able to demarcate the communal rangelands.

The son of caid Arabe became a district-officer in Azrou and embezzled the communal land of the village Ben Smim. Part of his revenues he invested in a large fondouk (local hotel) which started to operate in 1922. He owned 3000 sheep and 1000 ha private land in 1937 (A.N., D.A.I. dossier 407). For a comparison : most pastoralists did not own more than 100 sheep and some hectares of agricultural land. The caids of the Ait Abdi and Ait Arfa de Guigou have enriched themselves too at the expense of the ordinary tribesmen. They not only succeeded by filching land but also by using duty-labour for personal aims (Belghiti-Alaoui, $1978: 224)$. At the end of the colonial area it occurred the French government had to protect the caids against the fury of the tribesmen.

17 After independence the local government became composed of men who had been active in the movement for independence or men who at least had not collaborated with the French. Most tribal leaders therefore were not qualified for a position in local state burocracy and they lost the posts they occupied. Quite often the positions were occupied by people from the cities. However, they have played the same tricks as the caids did in the colonial period. They have profited considerably from the departure of the colons. Large agricultural farms, saw-mills, stores etc. were obtained for fancy prices or were obtained by force (Venema, 1992). In Morocco, and in the Middle Atlas, the government bureaucracy is not at all a goal-oriented smooth-running machine. The officials try to take advantage from their position. 


$$
\text { the possibilities to enrich onself after independence has considerably increased local }
$$
economic differentiation.

The myth of a homogeneous society from another point of view inhabitants of the Beni Mguild area originally came from elsewhere. The study of Belghiti-Alaoui (1978) showed that in 1880 Azrou was divided in two wards. The first was composed of houses of the lineage Ait Amer (of the tribe Irklaouan) and was called ighrem Aqdim. The other ward was inhabited by immigrants and was called ksar Ait Gheriss after the name of the inhabitants. According to oral tradition these Ait Gheriss, originating from the south, had arrived here in the second half of last century in order to take advantage of trading opportunities. In an attempt to protect themselves against robberies they preferred to have their ward walled in but this was prevented by the tribal leaders. Only when Sultan Hassan I had submitted the area, caid Aarabe allowed the inhabitants to start the construction of the wall.

So we see that immigrant traders had established themselves among the Beni Mguild quite early. They had not only settled themselves in Azrou but in Ain Leuh and Timahdite as well (Dabancens, 1951 ; A.N., D.A.I, dossier 401). But not only traders had arrived. As we already have seen the Beni Mguild area counted a number of woodcutters who worked on account of townspeople. After the 'pacification' more strangers settled in the rural areas. These immigrants worked as agricultural labourers, shepherds and guards (Laoust, 1935 ; Dabancens, 1951). Because the shepherds were renumerated against part of the increase of the herd they had access to the communal rangelands. Those shepherds who live since long in the area and who share village obligations and pay their fees are to be conceived of as having the same rights as the autochtonous population (A.N., D.A.I. dossier 407).

21 The flow of newcomers increased in the colonial area. As mentioned before, the Beni Mguild area had been pacified in the colonial area. Immediately thereafter the first colons arrived to build a livelyhood in agriculture, forestry or trade. Because of the arrival of foreigners the need of manpower was great, especially in construction works and agriculture. The centres of Azrou and Ain Leuh increased spectacularly in size. In the period 1926-1947 Azrou increased from 1593 to 7983 inhabitants and Ain Leuh from 1423 to 3817. The census showed that the major part of the inhabitants came from elsewhere (Beaudet, 1969). The strangers were especially people from the south, partly from Arabic partly from Berher origin (Ait Gheriss, Ait Morghad, etc.). After the Second World War many Riffis from the north came to this area because in their home-area it had become impossible to eke out an existance due to increasing population pressure.

22 Many immigrant families, especially the Ait Gheriss, were traders. Barter was quite common before the establishment of the Protectorate. Just before the Protectorate the pastoralists exchanged one or two lambs for one sugar-loaf (rital, about 1500 gram). These lambs were kept in the herd of the original owner but two-third of the increase belonged to the trader or shopkeeper. In this way traders who succeeded in doing business arrived to have herds of sheep of their own.

The increase of the population sided with an increase of land used for agriculture. The land under crops increased from 19.250 ha in 1930 to 32.900 ha in 1955, an increase of $71 \%$. (Beaudet, $1969: 35$ ). Because the grazing pressure on the pastures led to increasing tensions among the pastoralists, the Beni Mguild started to deny the 
recently arrived immigrants access to the communal pastures. They were no longer conceived as regular citizins. It seems that the first endeavours to exclude strangers to have tenure rights started since the forties.

However, these endeavours could not succeed because the Beni Mguild were notable to act as a whole. Some Bemi Mguild did not give in to pressures to chase strangers from the pastures but vindicated their personal aims. So some pastoralists made an arrangement with a newcomer. For a remuneration the indigenous herd owner was willing to add the strangers' herd to his own. To his fellow tribesmen he pretended all sheep were his. According to my informants conflicts between the original population and newcomers and increased suspicion between locals as regards secret arrangements would have started in the forties.

From what is said above it follows that the local population not only differed in wealth but that also a distinction has to be made between the indigenous and immigrant population. Leaving the market centres apart, in the rural area about a third of the total population originated from the outside (Bencherifa and Johnson, 1991 :192). The Beni Mguild appears not to be a homogenous population at all.

The herders' association project and what has been achieved

In the early eighties the grazing pressure was such that in average there were three sheep for every hectare pastureland while, according to calculations, only one sheep and a lamb for every hectare was the upper limit in order to prevent rangeland degradation. The erosion, which presented itself in gullies and soil subsidence, had become a major problem. An important reason for soil erosion was that several pastoralists no longer moved their herd between summer and winter pastures but had their herd grazing the same area continuously. Most often these herds remained in the less populated winter pastures. However, only farmers who could dispose of a fold and fodder in order to tide over the period of snow-fall were able to do this. In addition trucking in water was sometimes necessary. So only for the rich pastoralists livestock-keeping became sedentarized. Already at the end of the Protectorate many pastoralists had built a fold. In the period 1940-80 the Ait Arfa de Guigou had built 260 folds on the collective pastures and they had started cultivating barley and lucerne as foddercrops.

Although at first glance these developments in livestock production show as livestock intensification, this is not the case. The fact that folds were constructed on the communal pastures means that common land had been de facto appropriated. The owners of the folds started to chase the flocks from the other shepherds and, if necessary, they do it by force. Once they have established their authority they have their herd graze the area permanently. This means that the rest-time in early spring, allowing the regrowth of grass, is no longer respected. The abandonment of the rest-time as a custom has considerably contributed to the degeneration of the common pastures.

28 This individalistic behaviour follows logically from the desintegration of local patterns of cooperation and mutual consultation during the colonial area. Because of the possibilities of enrichment, clublaw had come very much to the fore. During the Protectorate the construction of folds had been connived at and the influentials, especially the tribal leaders have profited from it. Less influential lineage-members have accepted this state of affairs because of the collaboration between the French 
authorities and the tribal leaders. However. traditional forms of cooperation withered away.

At the end of the seventies the extent of land erosion was such that the Moroccan government and the World Bank agreed to intervene. At the start of the eighties the preliminary research started. It was decided to leave the pastures in communal use but to regulate it by the introduction of pastoral associations. These are groups of herders who have agreed to cooperate with the government. The associations would try to arrest land degradation by the introduction of stocking rates. In fact it was proposed that pasture ceiling would be introduced. The loss of income would be met by an increase in livestock production by improvement of animal husbandry and the development of agriculture. Livestock intensification would be achieved by means of breed improvement, the amelioration of veterinary services and the introduction of foddercrops. These crops could be cultivated on land that was left fallow. In certain areas it was encouraged to change cereal cultivation into horticulture.

Between 1983-1987 \$92 million was spent in the 'Projet Moyen Atlas'. The project obtained some tangible results. Several local roads have been constructed to facilitate contact with the veterinary service. Now it is also easier to reach the cattle market so that the herders can operate more efficiently. In addition several water point have been constructed which has decreaded the number of conflicts as regards access to water. The herders have a great interest to obtain pedigree rams and prices went up to high levels due to the increase in demand. Livestock -keepers with fertile land in the lower valleys have started with horticulture.

31 In the district Timahdite a dynamic caid, in collaboration with the rural council, the local judge and the lineage-elder have succeeded in determining the boundaries of the common pastures and in fixing a rotating schedule. If a contravention occurred the caid seized the cattle and is only returned after the owner has been fined. The role of the lineage-council and lineage-elder has become of minor importance. It is now the caid, the judge and the rural elected council who decide on land arrangements [see for the role of government officials in animal husbandry among the neighbouring Ait Ayash : Chiapuris (1980) and among the Ait Youssi : Geertz \& Rosen (1979)].

What not has been reached

On the other side the results of the project are disappointing. Until 1990 only three herders' associations had been created. When becoming a member of a herders' association one has in principle accepted to decrease the size of the herd while the government officials have promised to increase the productivity of the herd. It appears that members in the scarse period (winter) can obtain fodder (sunflower cake) with subsidy. They can also obtain prize money when the herd has improved in breed. Those who are member have the advantage that a veterinary assistant controls the herd in order to detect diseases and other problems. It proves that the government indeed tries to introduce a more intensive sheep husbandry.

It appears, however, that only a small number of herd owners has become member of the association. The association of Timahdite, Tarat, has 26 members with a total of 11.050 heads of sheep. The association of Ain Leuh, Tithissi, has 22 members with a total of came of 13.060 head. The third association, Amghass, has 16 members with 15.000 head. By estimation only about $1 \%$ of the livestock-owners is a member of an association. In 1985 the total number of sheep among the Beni Mguild was estimated at 650.000 head : the number of sheep in associations (about 6\%) is small indeed. 
The members of the associations in average owned 610 heads of sheep. The range was between 150 and 1200 sheep. So it appears that especially the rich pastoralists have become a member. For the poor livestock-keepers the entrance-fee is already too high. In order to have a working capital the entrance fee amounts to 400 dirham, equaling the value of a sheep.

But there is something else which matters here too. It appears that the poor herdsmen have in fact no access to the pastoral association. The large herd owners of the association argue that they do not have the wherewithal to build up a fine herd. For example they are not in the possibility to buy fodder of sufficient quality for the winter period. In addition they do not own a sheep-fold. The members of the association appear not to accept as a member somebody with a poor herd which may detiorate the quality of the common herd. In addition, they prefer to keep the prizes and subsidies for themselves. The president of the association of Ain Leuh is a very large herd owner who only accepts family-members to enter the association. The president of the association of Timahdite is a rich herd owner too who only accepts family-members and rich acquintances. Small herdsmen explained to me they not even dared to ask to become a member if there was no family-relationship.

The aim to achieve a reduction in number of cattle has not been met. The members of the association are big livestock owners and they want to remain it that way. The rural council too did not succeed to introduce destocking. The reason is that the council is composed of big herd owners. If we take the 45 members of the three rural councils (Irklaouan, Ait Abdi and Ait Arfa du Guigou) together, then 35 own more than 200 heads of sheep. Members of the rural council are in the board of the pastoral association too. So the president of the council of Timahdite is president of the herders' association too, while the president of the association of Ain Leuh is even a member of the Provincial Council. So from the council-members little initiative in destocking can be expected. failure in view of the low membership rate. Those who have become a member cash in the profits but they do not decrease their herd as has been promised to the project authorities. Land degradation therefore continues to be an important phenomenon in this area.

The free play of societal forces or a role to play by the state?

Despite the encouragements of the government the population has not prevented the process of land degradation to continue. A major role was played by the big herd owners who have blocked the pastoral association project.

However, on some domains the government has succeeded to implement land-use policy. After discussion with the World Bank the government has decided to prevent new constructions of folds on the common pasture to delimit overgrazing of the land. Each transgression will be fined and the Provincial Commissioner himself is charged with the implementation. Due to the fact that pastureland now has become a scarse resource, pastoralists react to every violation by informing the local authorities. The building of folds on common pastures bas become past practice.

The government appears to play a major role in the protection of the- rights of the settled immigrant population. Most large herd owners, even those in the councils, want to go as far to expel the cattle of all strangers, even from those already inhabiting the area for more than a generation. As an example we may refer to the Ait Khaoua, 
originally from Missour, but a1ready living with the Ait Abdi since the twinties. They formally counted fourteen families and they earned their money as shepherds for the Ait Abdi. Now they number 45 families and they have their own flocks, amounting to 6000 head in total (Belghiti-Alaoui, $1978: 190,225$ ). Up to today there is regularly a mêlée between the Ait Abdi and the Ait Khaoua. The district-officer intervenes regularly to protect the latter. Disputes between the original population and immigrant families are common among the Beni Mguild.

41 It appears that the local authorities have obtained strict orders from the central government to protect the immigrant families. This means that those already settled and having their own flock cannot be denied the access to the pastures. The notion of property from the point of view of the central government protects here the rights of immigrants.

Recently the local authorities and the rural councils have, without many problems, decided to prevent the introduction of herds on the pastures by new immigrants. This is endorsed by the big herd-owners. Nevertheless it appears quite difficult in practise to prevent new outsiders introducing herds on the common pastures. -So it happens that a livestock-keeper who has sold his herd is contacted by a newcomer who offers him money to rent his share in the pasture in order to be able to increase his herd. Then he buys an additional herd and introduces it on the common pasture but tells to everybody he is only the shepherd and the herd is owned by somebody else. Due to completion now this type of transactions are always passed on to the state officials. The district officers intervenes but rumours have that 'renting of shares' is still practice and, indeed, is more difficult to prevent than the building of folds.

Conclusion

From the foregoing it is clear that it is very difficult to decrease the number of cattle, although it is an imperative to arrest land degradation.

Our case shows that the livestock-owners do not live together in an egalitarian society although this is often stated for pastoral societies. Among the population of the Middle Atlas 'big men' have always presented themselves and local stratification only increased in the colonial period. The tribal land, in theory open for all tribesmen, appeared de facto been appropriated by the big herd owners by the building of folds and the trucking of water. The introduction of the 'pastoral association project' only did increase economic stratification because the rich pastoralists captured the association. So only the rich herd owners profited from the advantages connected with the association. To argue that common land opens opportunity for the poor and for this reason must be maintained, seems not to be quite realistic (Jodha, 1991).

Because the Beni Mguild society is stratified, new organizations introduced from the outside become incorporated in local power networks. Both the pastoral association as well as the rural council are in the hands of the rich herd owners. The consequence is that they are able to block the destocking policy. When the creation of local institutions is left over to the local population, local power stratification will only be enforced. We disagree with the point of view of the World Bank which states: "To succeed, cooperation has to be voluntary and managed from below. Grassroots management is one way to ensure this. Alternatively, cooperatives can be based on customary social structures and groups as they often are" (1989: 103, see also Swift, 1991). My point of view is that traditional organizations and leadership have been undermined and have 
not incorporated new functions. The two World Bank officials have based their conclusions on insufficient research.

Attwood a.o. (1988:50-53) have argued that destocking programs in livestock projects are difficult to achieve. The Beni Mguild herdsmen have refused to do so. Instead of regulating the size of their own flock, they try to inhibit the access to pastureland by 'outsiders' although most live in the area already a generation or even more. This resulted in numerous conflicts about access to the pastures. It is very strange that in livestock projects the rights of the immigrant families is hardly acknowledged. Not only among the Middle Atlas population there are immigrants. This is also the case in other parts of Morocco and in other countries : the former 'closed' resources appear to be open for 'outsiders' (see a.o. Dyson-Hudson, 1985 ; Shepherd, 1989).

4 It is clear that arresting land degeneration cannot be brought about by local management. In the current rhetoric of the withdrawal of the state such notions may appear popular but they pass over the hard reality of internal polarisation. The degree of internal conflicts is such that the government has to play much more than a supportive role. We agree with Lawry (1989) that the local communities together with the government have to look for solutions. And then we cannot do without certain policies imposed from above.

8 In view of the hierarchical and even feudal relationships in Morocco the role of the large livestock-owners cannot be restrained by the local population itself. Although the Moroccan government is itself an expression of the society it appeared that the government is able to choose between several policy options. So the World Bank and the central government have succeeded to implement several policies, making use of the individualism and completion among the livestock-owners.

As is stated by Redcliff (1987:200), if we rely too much on the market forces then the right of the strongest will dictate the course of events. Livestock projects in stratified societies which want to offer opportunities to \&l members of the community can only be successful if concrete support is given by the central government

\section{BIBLIOGRAPHIE}

Attwood, D.W. a.o.(1988) Power and Poverty. Development and Development Projects in the Third World. Boulder and London : Westview Press.

Beaudet, G. (1969) Les Beni Mguild du Nord. Géographie de l'Evolution Récente d'une Conféderation Semi-nomade. Revue de Géographie du Maroc, 15.

Belghiti-Alaoui, A. (1978) Urbanisation et Domination du Monde Rural :l'Exemple d'Azrou. Thèse de Doctorat, Un. de Toulouse-Le Mirail, Inst de Géographie.

Bencherifa, A. and D.L.Johnson (1991) Changing Resource Management Strategies and their environmental impact in the Middle Atlas Mountains of Morocco. Mountain Research and Development, 3. 
Chiapuris, J.P. (1980) The Ait Ayash of the Central Atlas : a Study of Social Organization in Morocco. Ann Arbor, Un. Microfilm Int.

Dabancens, (1951) Les Ait Abdi du Moyen Atlas et leurs réactions au contact des étrangers. Cahiers d'Outremer (4).

Dyson-Hudson, N. (1985) Pastoral Production Systems and African Experience. In M.M. Cernea : Putting People First. Variables in Rural Development. New York : Oxford Un. Press.

Eicher, C.K. and D.C. Baker (1982) Research on African Development in Sub-Saharan Africa :-a Critical Survey. Michican State University, Intern. Development Paper $n^{\circ} 1$.

FAO/Netherlands (1991) Livestock Production and Health for Sustainable Agriculture and Rural Development. FAO/Min. van Landbouw, Backgr. doc. 3, Conference on Agriculture and the Environment's Hertogenbosch.

Social and Institutional Aspects of Sustainable Agriculture and Rural Development. FAO/Min. van Landbouw, Backgr. doc. 5, Conference on Agriculture and the Environment's Hertogenbosch.

Foucault, C. de (1985) Reconnaissance au Maroc, 1883-1884. Paris : Les Introuvables. Editions d'Aujourd'hui.

Geertz, C. and H. and L. Rosen (1979) Meaning and Order in Moroccan Society: Three Essays in Cultural Analysis. Cambridge Un. Press.

Jodha, N.S. (1991) Rural Common Property Resources. The Gatekeeper Series. Intern. Institute for Environment and Development.

Laoust, E. (1935) L 'Habitation chez les Transhumants du Maroc Central. Paris, Larose.

Lawry, S.W. (1989) Tenure Policy toward Common Property Natural Resources. Land Tenure Center Paper, $\mathrm{n}^{\circ} 134$. Wisconsin.

Redclift, M. (1987) Sustainable Development. Exploring the Contradictions. London : Methuen en Co.

Rohlfs, G.A. (1868) Reise durch Marokko, Uebersteigungen der grosse Atlas, Exploration etc. Bremen, Verlag von 1. Kühtmann's Buehhaltung.

Shepherd, G. (1989) The Reality of the Commons : Answering Hardin from Somalia. Development Policy Review, 7 (1).

Swift, J. (1991) Local Customary Institutions as the Basis for Natural Resource Management among Boran Pastoralists in Northern Kenya. IDS-Bulletin, 22 (4).

Venema, B. (1992) Het Ontstaan van een Lokale Elite in een Plattelandsdistriet van Marokko : de Relatie met Nationale Ontwikkelingen. Sharqiyyat 4(2).

World Bank (1989) Sub-Saharan Africa. From Crisis to Sustainable Growth. A Long-Term Perspective.

A.N. D.A.I. Archieven Nantes, Section Outre-Mer, Direction des Affaires Indigènes. 